\title{
Front Matter: Volume 7411
}

, "Front Matter: Volume 7411," Proc. SPIE 7411, Nanoscale Photonic and Cell Technologies for Photovoltaics II, 741101 (14 September 2009); doi: $10.1117 / 12.844872$

SPIE Event: SPIE Solar Energy + Technology, 2009, San Diego, California, United SPIE. States 


\section{PROCEEDINGS OF SPIE}

\section{Nanoscale Photonic and Cell Technologies for Photovoltaics II}

Loucas Tsakalakos

Editor

2-4 August 2009

San Diego, California, United States

Sponsored and Published by

SPIE 
The papers included in this volume were part of the technical conference cited on the cover and title page. Papers were selected and subject to review by the editors and conference program committee. Some conference presentations may not be available for publication. The papers published in these proceedings reflect the work and thoughts of the authors and are published herein as submitted. The publisher is not responsible for the validity of the information or for any outcomes resulting from reliance thereon.

Please use the following format to cite material from this book:

Author(s), "Title of Paper," in Nanoscale Photonic and Cell Technologies for Photovoltaics II, edited by Loucas Tsakalakos, Proceedings of SPIE Vol. 7411 (SPIE, Bellingham, WA, 2009) Article CID Number.

ISSN 0277-786X

ISBN 9780819477019

Published by

SPIE

P.O. Box 10, Bellingham, Washington 98227-0010 USA

Telephone +1 3606763290 (Pacific Time) · Fax +1 3606471445

SPIE.org

Copyright (C) 2009, Society of Photo-Optical Instrumentation Engineers

Copying of material in this book for internal or personal use, or for the internal or personal use of specific clients, beyond the fair use provisions granted by the U.S. Copyright Law is authorized by SPIE subject to payment of copying fees. The Transactional Reporting Service base fee for this volume is $\$ 18.00$ per article (or portion thereof), which should be paid directly to the Copyright Clearance Center (CCC), 222 Rosewood Drive, Danvers, MA 01923. Payment may also be made electronically through CCC Online at copyright.com. Other copying for republication, resale, advertising or promotion, or any form of systematic or multiple reproduction of any material in this book is prohibited except with permission in writing from the publisher. The CCC fee code is 0277-786X/09/ $\$ 18.00$.

Printed in the United States of America.

Publication of record for individual papers is online in the SPIE Digital Library.

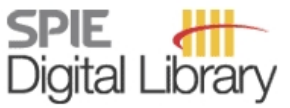

SPIEDigitalLibrary.org

Paper Numbering: Proceedings of SPIE follow an e-First publication model, with papers published first online and then in print and on CD-ROM. Papers are published as they are submitted and meet publication criteria. A unique, consistent, permanent citation identifier (CID) number is assigned to each article at the time of the first publication. Utilization of CIDs allows articles to be fully citable as soon they are published online, and connects the same identifier to all online, print, and electronic versions of the publication. SPIE uses a six-digit CID article numbering system in which:

- The first four digits correspond to the SPIE volume number.

- The last two digits indicate publication order within the volume using a Base 36 numbering system employing both numerals and letters. These two-number sets start with 00, 01, 02, 03, 04, $05,06,07,08,09,0 A, 0 B \ldots 0 Z$, followed by 10-1Z, 20-2Z, etc.

The CID number appears on each page of the manuscript. The complete citation is used on the first page, and an abbreviated version on subsequent pages. Numbers in the index correspond to the last two digits of the six-digit CID number. 


\title{
Contents
}

\author{
vii Conference Committee \\ ix Introduction \\ xi Concentrating solar energy for utility scale applications (Plenary Paper) [7407-106]
}

R. Sherif, eSolar, Inc. (United States)

xvii Recent progress in photocatalysts for overall water splitting under visible light (Plenary Paper) [7408-103]

T. Hisatomi, K. Domen, The Univ. of Tokyo (Japan)

xxix Photovoltaic-reliability R\&D toward a solar-powered world (Plenary Paper) [74 12-104]

S. Kurtz, National Renewable Energy Lab. (United States); J. Granata, M. Quintana, Sandia National Labs. (United States)

INORGANIC NANO SOLAR CELLS I

741103 Synthesis and structural properties of Ge nanocrystals in multilayer superlattice structure [7411-02]

B. Zhang, S. Shrestha, P. Aliberti, M. A. Green, G. Conibeer, Univ. of New South Wales (Australia)

INORGANIC NANO SOLAR CELLS II

741106 Temperature dependence of hot carrier relaxation in PbSe nanocrystals: an ab initio study (Invited Paper) [7411-06]

H. Bao, Purdue Univ. (United States); B. F. Habenicht, O. V. Prezhdo, Univ. of Washington (United States); X. Ruan, X. Xu, Purdue Univ. (United States)

741107 Light harvesting in hybrid epitaxial/colloidal nanostructures [7411-07]

P. G. Lagoudakis, S. Chanyawadee, Univ. of Southampton (United Kingdom)

741108 Growth and characterization of $\mathrm{Cu}_{2} \mathrm{ZnSnS}_{4}$ nanostructures using anodized aluminum as the growth mask [7411-08]

C. P. Chan, Z. Chen, H. Lam, C. Surya, The Hong Kong Polytechnic Univ. (Hong Kong, China)

NANOSTRUCTURED ORGANIC AND HYBRID SOLAR CELLS I: JOINT SESSION WITH CONFERENCE 7416

7411 OA High-performance dye-sensitized solar cells with nanomaterials as counter electrode [7411-11]

X. Mei, B. Fan, K. Sun, J. Ouyang, National Univ. of Singapore (Singapore) 
$7411 \mathrm{OB} \quad$ Effects of DNA and Pt-DNA electrodes on bulk heterojuction solar cells [7411-12]

E. Yengel, L. Wang, M. Ozkan, C. S. Ozkan, Univ. of California, Riverside (United States)

\section{NANOPHOTONICS FOR PHOTOVOLTAICS I}

7411 OD Third generation photovoltaics (Invited Paper) [7411-14]

G. Conibeer, Univ. of New South Wales (Australia)

$74110 \mathrm{E} \quad$ Upconverted fluorescence in Er-doped ZBLAN glasses for high efficiency solar cells [7411-15]

B. Henke, Fraunhofer Ctr. for Silicon Photovoltaics (Germany); B. Ahrens, Univ. of Paderborn (Germany); J. A. Johnson, The Univ. of Tennessee Space Institute (United States); P. T. Miclea, S. Schweizer, Fraunhofer Ctr. for Silicon Photovoltaics (Germany) and Martin-Luther-Univ. of Halle-Wittenberg (Germany)

\section{NANOPHOTONICS FOR PHOTOVOLTAICS II}

$74110 \mathrm{Ol} \quad$ Plasmonic and biomimetic light-trapping for photovoltaics [7411-19]

T. L. Temple, S. A. Boden, D. M. Bagnall, Univ. of Southampton (United Kingdom)

\section{NANOPHOTONICS FOR PHOTOVOLTAICS III}

$74110 \mathrm{M} \quad$ Study of LSPR-enhanced absorption for solar cell applications: preliminary results [7411-23] O. Guilatt, Ben-Gurion Univ. of the Negev (Israel); B. Apter, Holon Institute of Technology (Israel); U. Efron, Ben-Gurion Univ. of the Negev (Israel) and Holon Institute of Technology (Israel)

$74110 \mathrm{~N}$ Transport and structural characterization of solution-processable doped ZnO nanowires [7411-24]

R. Noriega, L. Goris, J. Rivnay, J. Scholl, L. M. Thompson, A. C. Palke, J. F. Stebbins, A. Salleo, Stanford Univ. (United States)

$741100 \quad$ Photonic band-engineering absorption enhancement of amorphous silicon for solar cells [7411-25]

O. El Daif, Univ. de Lyon, Institut des Nanotechnologies de Lyon, CNRS-INSA-ECL-UCBL (France), Ecole Centrale de Lyon (France), and INSA de Lyon (France); E. Drouard, G. Gomard, Univ. de Lyon, Institut des Nanotechnologies de Lyon, CNRS-INSA-ECL-UCBL (France) and Ecole Centrale de Lyon (France); Y. Park, A. Kaminski, A. Fave, M. Lemiti, Univ. de Lyon, Institut des Nanotechnologies de Lyon, CNRS-INSA-ECL-UCBL (France) and INSA de Lyon (France); X. Letartre, P. Viktorovitch, Univ. de Lyon, Institut des Nanotechnologies de Lyon, CNRS-INSA-ECL-UCBL (France) and Ecole Centrale de Lyon (France); S. Ahn, H. Jeon, Seoul National Univ. (Korea, Republic of); C. Seassal, Univ. de Lyon, Institut des Nanotechnologies de Lyon, CNRS-INSA-ECL-UCBL (France) and Ecole Centrale de Lyon (France) 
POSTER SESSION

$74110 \mathrm{~V}$ One aspect of solar cell efficiency: multiple wavelengths photon absorption in nano-silicon structures [7411-32]

J. S. Nayyar, A. Kulkarni, Michigan Technological Univ. (United States)

Author Index 
Downloaded From: https://www.spiedigitallibrary.org/conference-proceedings-of-spie on 26 Apr 2023

Terms of Use: https://www.spiedigitallibrary.org/terms-of-use 


\title{
Conference Committee
}

\author{
Symposium Chair \\ Martha Symko-Davies, National Renewable Energy Laboratory (United \\ States) \\ Conference Chair \\ Loucas Tsakalakos, GE Global Research (United States) \\ Program Committee \\ Eray S. Aydil, University of Minnesota (United States) \\ Alberto Salleo, Stanford University (United States) \\ Joop Schoonman, Technische Universiteit Delft (Netherlands) \\ Sean E. Shaheen, University of Denver (United States) \\ Wilfried G. J. H. M. van Sark, Universiteit Utrecht (Netherlands) \\ Xianfan Xu, Purdue University (United States)
}

Session Chairs

1 Inorganic Nano Solar Cells I

Loucas Tsakalakos, GE Global Research (United States)

2 Inorganic Nano Solar Cells II

Loucas Tsakalakos, GE Global Research (United States)

3 Nanostructured Organic and Hybrid Solar Cells I: Joint Session with Conference 7416

Sean E. Shaheen, University of Denver (United States)

$4 \quad$ Nanostructured Organic and Hybrid Solar Cells II: Joint Session with Conference 7416

Dana C. Olson, National Renewable Energy Laboratory (United States)

5 Nanophotonics for Photovoltaics I

Wilfried G. J. H. M. van Sark, Universiteit Utrecht (Netherlands)

6 Nanophotonics for Photovoltaics II

Xianfan Xu, Purdue University (United States)

$7 \quad$ Nanophotonics for Photovoltaics III

Eray S. Aydil, University of Minnesota (United States) 
Downloaded From: https://www.spiedigitallibrary.org/conference-proceedings-of-spie on 26 Apr 2023

Terms of Use: https://www.spiedigitallibrary.org/terms-of-use 


\section{Introduction}

The solar energy industry has seen strong growth in the last decade. While the recent recession has certainly had a big impact on the photovoltaics (PV) industry through a lack of credit that has seen inventories soar and prices for $\mathrm{Si}$ modules drop to unprecedented levels, it is expected that in the long run the industry will again see good growth levels. Indeed, the emergence of CdTe thin film technology as a major rival to silicon underscores this point. Conventional silicon and thin film PV technologies are well developed and capable of meeting the clean energy demands of many markets. Nevertheless, there continues to be interest within the research community in developing technologies that can simultaneously reduce cost yet also provide breakthrough performance.

To this effect, research efforts in studying and applying the unique optical, electrical, and structural/architectural properties of nanostructures to solar energy applications, either as novel photonic structures or as new solar cell device structures, continue to flourish. This year's second installment of the conference devoted to this topic 17411: Nanoscale Photonic and Cell Technologies for Photovoltaics II), held at SPIE Optics \& Photonics in 2009 as part of the Solar Energy + Technology Symposium, once again demonstrated the strong interest in this field of research.

The first two sessions of the conference were focused on Inorganic Nano Solar Cells. Recent developments in Si and II-VI wire, group IV quantum dots, and II-VI nanocrystal solar cells were presented. The third and fourth sessions were in fact joint session with the Organic Photovoltaics conference, and featured advances in Nanostructured Organic and Hybrid Solar Cells. These included application of fullurenes to bulk heterojunction solar cells, new electrodes, dye-sensitized solar cells, and the new results in plasmonics for excitonic PV devices. The final three sessions of the conference were devoted to the application of Nanophotonics for Photovoltaics, i.e. the use of novel layers and structures for light management in PV applications. After a broad overview of $3^{\text {rd }}$ Generation Photovoltaics, numerous presentations on up-conversion, plasmonics, light trapping, nanowirebased transparent conductors, and photonic bandgap structures, among other topics, were given. A collection of excellent posters on various nanostructured PV topics further contributed to the conference.

The conference was also highlighted by the addition of a panel discussion on Commercialization of Next Generation Solar Technologies, in which experts from academia and industry discussed the prospects and challenges in developing novel PV technologies based on organic and inorganic structures. The panelists were as follows: 
Harry A. Atwater, Jr., California Institute of Technology (United States)

Gilles Dennler, Konarka Austria Forschungs und Entwicklungs $\mathrm{GmbH}$ (Austria)

Damoder Reddy, Solexant (United States)

Christiana B. Honsberg, Arizona State Univ. (United States)

Darin W. Laird, Plextronics Inc. (United States)

Moritz K. Riede, IAPP, Technische Univ. Dresden (Germany)

Wladek Walukiewicz, RoseStreet Labs (United States)

James H. Ermer, Spectrolab, Inc. (United States)

Some panelists argued Si will continue to be an important technology in the PV industry and hence new technologies enhancing Si would emerge, whereas others argued that novel polymer and nanoscale inorganic solar cells will fundamentally alter the PV landscape in years to come, though it was noted that the various technologies under development are not necessarily mutually exclusive. Researchers working on conventional PV technologies noted an interest in better understanding the unique characteristics of advanced PV concepts, and a strong interest in concentrator PV was also shown by a robust discussion on the topic. The large audience turnout and participation pointed to the continued strong interest in the development of advanced photovoltaic concepts.

Once again, the conference provided an excellent forum for the interchange of advanced/nanoscale photonic and device concepts in photovoltaics. I would like to thank the conference program committee (Drs. E. S. Aydil, A. Salleo, J. Schoonman, S. E. Shaheen, W. G. J. H. M. van Sark, and X. XU) for their support, as well as the session chairs, authors, and SPIE staff for their help in making this a successful conference. The strong support of Dr. M. Symko-Davies, chair of the 2009 Solar Energy + Technology symposium, is also greatly appreciated.

Loucas Tsakalakos 